Pavlov Y. V., Candidate of Pedagogical Sciences

The National Academy of the National Guard of Ukraine

Kharkiv, Ukraine

DOI: https://doi.org/10.30525/978-9934-26-028-5-11

\title{
TECHNOLOGY OF INTERACTION OF THE MILITARY UNIT WITH SUPPLIERS IN PROVIDING LOGISTIC PROCESSES OF BODY SUPPORT
}

Supply issues have traditionally been in the area of special attention of the military command, which is explained by the significant impact of the effectiveness of supply chain management on the problem of maintaining the combat readiness of military units. Effective management of logistics supply processes can increase the final cost savings of the military unit through the use of supplier selection and supply functions.

The analysis of specialized literature [1-7] shows that the study of the interaction of the military unit with suppliers in the logistics processes of logistics is an urgent scientific task. However, certain areas of research do not include technology for selecting suppliers for military units. Thus, the aim of the thesis is to improve the technology of interaction of the military unit with suppliers in the logistics processes of logistics in accordance with the requirements of procurement logistics.

All business transactions related to the interaction of the military unit with suppliers must be documented by accompanying documents: orders, information, acts, orders, warrants, invoices, certificates, etc., which participate in the document flow.

Written evidence of a transaction that has legal (evidentiary) value is called the primary accounting document. The primary document is 
drawn up at the time of the transaction, and if this is not possible immediately after its completion.

Completed primary accounting documents must meet the following requirements [6]:

1) contain complete and reliable data;

2) contain mandatory details;

3) quickly check the form. Verified and processed documents must have an evaluation that excludes the possibility of their reuse;

4) consist of means that ensure the safety of records for a long time.

It is important to emphasize that the primary documents are drawn up on the basis of the submitted documents (contracts, invoices, transport invoices, orders, etc.). This rule of substantiation of the executed documents provides performance of the following elements of a method of double record [7]:

1) the same amount of the transaction will be recorded on the corresponding accounts;

2) within each of the two accounts involved in the transaction, debit and credit entries will be correlated with each other.

On the basis of the received and checked primary documents in accounting service the order of the account of each made business transaction is defined, namely:

1) the content and date of the operation are determined;

2) a monetary valuation of the transaction (the amount of the transaction);

3 ) the corresponding correspondence of accounts is determined.

All specified information on transactions must be recorded in the accounting documents.

The list of documentary reporting that should be used in the interaction of the military unit with suppliers is presented in Figure 1.

Planning and carrying out procurement and delivery activities begins with the selection of appropriate suppliers. Identification and study of sources of procurement and supply is not a one-time event, but should be carried out systematically, based on different sources of information (Figure 2). 


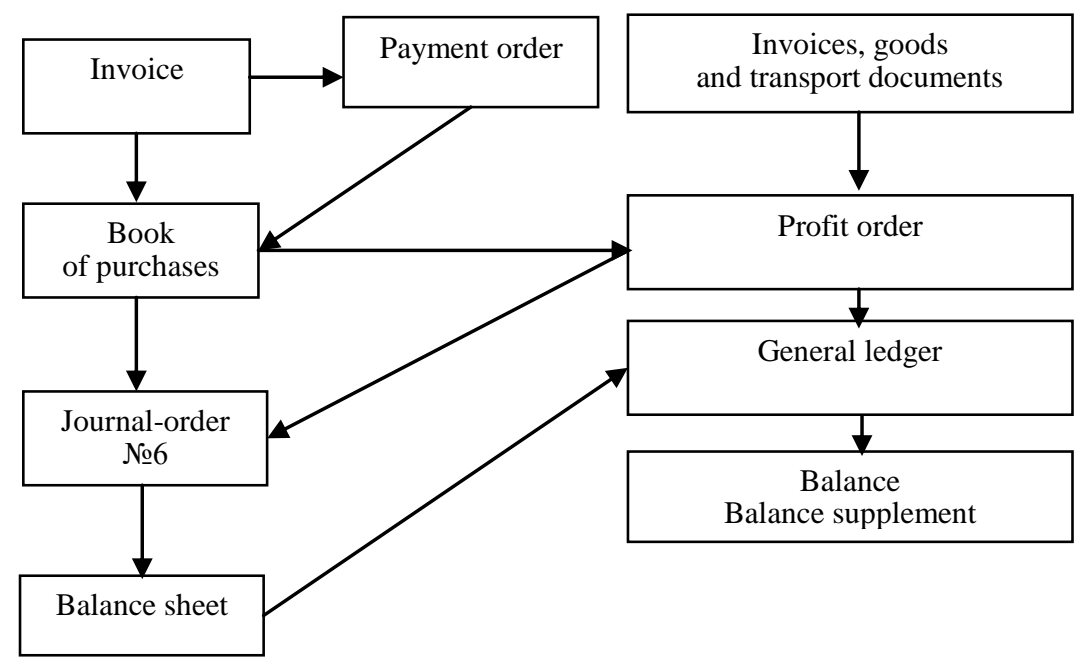

Figure 1. The scheme of document flow
of the military unit with suppliers

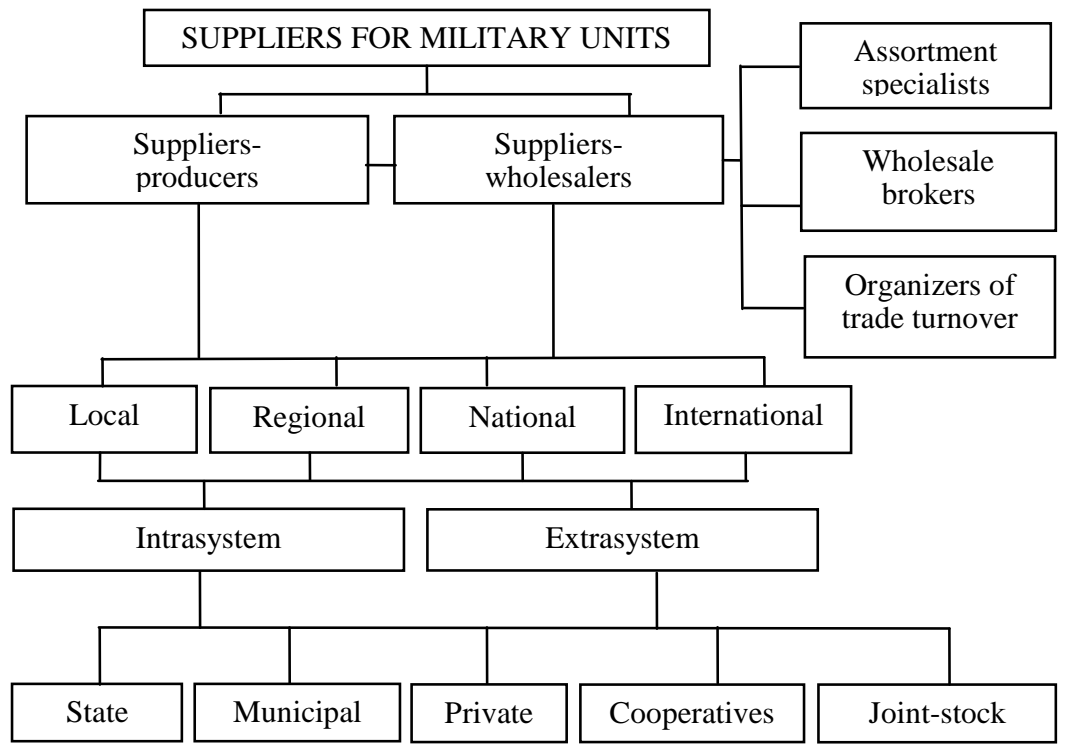

Figure 2. Classification of suppliers of military units 
Catalogs (in printed or electronic form), trade magazines, various advertisements, price lists, trade directories (registers) of suppliers and goods, trade representations, etc. can act as usual sources of information.

Catalogs of the most well-known sources of supply contain, for example, information on production sources, offers, the list of the goods which are available at distributors, the prices, the sizes of discounts, etc.

Thus, the diversity and large number of potential suppliers of the required products makes it very important to choose those that could most effectively provide effective logistics of the military unit.

\section{References:}

1. Bashkirov N., Khairbekov Z. (2014) Kontseptual'nye osnovy tylovogo obespecheniya Vooruzhennykh sil SShA [Conceptual framework for logistics support for the U.S. Armed Forces]. Zarubezhnoe voennoe obozrenie, no. 5, pp. 28-33.

2. Volkova E., Portnova G.A. (2007) Osnovnye problemy upravleniya material'nymi zapasami: tezi dop. VI vseukr. nauk. stud. konf. Aktual'ni pitannya menedzhmentu v suchasnikh umovakh. Donets'k: Donetskiy natsional'nyy tekhnicheskiy universitet, pp. 288-290.

3. Chebotarev S.S., Popova Yu.V. (2015) Logistika voysk NATO [NATO troop logistics]. Vestnik Akademii voennykh nauk, no. 2 (51), pp. 152-157.

4. Ishchenko, O. V. Orhan upravlinnia systemoiu materialno-tekhnichnoho zabezpechennia Zbroinykh Syl Ukrainy, yakym yomu buty? Tsentr voiennoi polityky ta polityky bezpeky. Available at: http://defpol.org.ua. 2010.

5. Gilmore D. A. Decade of Supply Chain Management. Supply Chain Digest.

6. Fisun K.A., Naumenko M.O. (2019) Tekhnolohiia upravlinnia protsesamy informatsiinoi pidtrymky lohistychnoho zabezpechennia viiskovykh chastyn ta pidrozdiliv [Technology of management of processes of information support of logistical support of military units and divisions]. Zbirnyk "Chest $i$ zakon», no. 4, pp. 96-101. 